\title{
Comments
}

\section{INDIAN TAXATION: UNDERLYING POLICIES AND PRESENT PROBLEMS}

Solution of the "Indian problem" has been a national goal since the first white settlers in America decided that they wanted Indian land without Indians. ${ }^{1}$ At first the remedy attempted was isolation of Indians on undesirable tracts of land. As the white settlers moved farther west, however, making available land more scarce, the problem became how to enable the Indian to live within the predominately white society of the Umited States. ${ }^{2}$ The Indians' poverty ${ }^{3}$ and their determination to retain their heritage ${ }^{4}$ have been the important impediments to this latter goal. Past policies have failed primarily because they were not addressed to both of these crucial considerations. Instead the Indians were made economically and politically dependent on the federal government and thereby deprived of the opportunity to formulate the rules which governed their lives, or they were summarily abandoned to cope with a fre-

1. See Fannin, Indian Education, 10 ARIz. L. REv. 661 (1968). See also D.M. MCNicol, The AMerican Indians 205-44 (1937); Subcomm. on Indian Education of the Sen. Comm. on Labor and Public Welfare, indian Education: A National Tragedy-A National Challenge, S. Rep. No. 501, 91st Cong., 1st Sess. 9-21 (1969) [hereinafter cited as A National Tragedy]; Collier, Policies and Problems in the United States, in The North AMERICAN Indian TOday 140-45 (C.T. Loram \& T.F. McIlwraith eds. 1943); Kelly, Indian Adjustment and the History of Indian Affairs, 10 ARrz. L. Rev. 559, 563-65 (1968).

2. See Johnson, American Indians in Rural Poverty, in Subcomm. on Economy in Government of the Jornt Economic Committee, 91st Cong., 1st Sess., Toward Economic Development for Native American Communities 19, 20, 35 (Comm. Print 1969) [this compendiun of papers hereinafter cited as Toward Economic Development]; Bennett, Problems and Prospects in Developing Indian Communities, 10 ARIZ. L. REv. 649, 652-57 (1968).

3. See generally a National Tragedy 9; Subcomm. on Indian Education of the Sen. Comm. on Labor and Public Welfare, The Education of american INDIANS, 91st Cong., 1st Sess. 35 (1969); Berger, Indian Mineral Interest-A Potential for Economic Advancement, 10 ARIz. L. REv. 675 (1968); Jenny, The American Indian: Needs and Problems, in Towaro Economic DeVelopment 46, 50; Johnson, supra note 2, at 19-20; Taylor, Indian Manpower Resources: The Experiences of Five Southwestern Reservations, 10 ARIZ. L. REv. 579 (1968); Wolf, Needed: A System of Income Maintenance for Indians, 10 ARIZ. L. REV. 597 (1968); Comment, Indians: Better Dead than Red?, 42 S. CAL. L. Rev. 101 (1969).

4. See Lintou, Land Tenure in Aboriginal America, in The Changing Indian 42, 43-44 (O. La Farge ed. 1942); see generally Comment, The Indian Stronghold and the Spread of Urban America, 10 ARIZ. L. Rev. 706, 707-13 (1968). 
quently hostile society when they were economically and culturally unprepared. 5 The realization that a successful Indian policy must provide Indians substantial economic development while also affording them an opportunity for self-determination is an important step toward solving the Indian problem, but the difficulty of how to effectuate this policy remains. ${ }^{6}$

A means of attacking the problem can be derived from present law virtually without new legislation by immunizing Indian property and activity on the basis of either of two existing national policies: providing Indians with federally protected land to serve as a base for economic betterment and affording Indian tribes some sovereignty from state and local government. ${ }^{7}$ That the federal income and estate tax laws implicitly contain Indian-related ${ }^{8}$ exemptions is a logical and necessary conclusion if contradiction of these federal policies is to be avoided. ${ }^{\circ}$ These same policies, through the supremacy clause, ${ }^{10}$ also require Indian-related exemptions from the state inheritance tax, possessory interest tax, income tax, and sales tax laws. ${ }^{11}$

5. Federal policy has run the gamut between treating Indians as incompetent wards who are given little or no say in programs affecting their lives and treating them as burdens who should be removed from public assistance. The former policy naturally caused resentment and then apathy among the Indians. The latter, typically accompanied by a program of allotting unrestricted land to individual Indians, resulted ultinately in substantially decreased land ownership because the Indians were not prepared, economically or culturally, to live on the white man's terms. On the history and development of federal Indian policy, see generally Berger, supra note 3, at 675 . 83; Kelly, supra note 1, at 563-73; Counment, The Indian Battle for Self-Determination, 58 CALIF. L. REv. 445 (1970). For a discussion of the Indians' loss of land following the Allotment Act of 1887 [25 U.S.C. $\$ 331$ (1964)], see A National Traocdy $9,12$.

6. Strong evidence that the federal government is aware of the importance of providing Indians with both economic aid and the opportunity for self-realization was given when the Vice President of the United States said:

We in this Administration believe in giving you control over what you

have. The reservations are your lands. The lives you lead on them are your hives. The federal government has obligations to provide financial support. But you should establish the priorities, you sliould allocate the funds, you should guide the projects. . . .

Los Angeles Times, Mar. 9, 1971, \&1, at 16, cols. 1, 2.

7. For a discussion of the federal policy of providing cconomic aid to Indians, see text accompanying notes 12-19 infra; for a discussion of the tribal-sovereignty doctrime, see text accompanying notes 20-26 infra.

8. This Comment uses the term "Indian-related" to describc the tax exemptions because the immunities are not limited to property owned by, or activity performed by, Indians. This follows logically from the argument advanced herein that the validity of any tax must depend upon its effect on the federal policies to provide Indians protected land and tribal sovereignty from state control.

9. See text accompanying notes 124-40, 164-71 infra.

10. U.S. CONST. art. VI.

11. See text accompanying notes $111-20,155-63,172-80,186-92$ infra. 


\section{SOURCES OF INDIAN-RELATED TAX EXEMPTIONS}

\section{A. The Commitment to Economic Development}

Today's American Indians would be aptly described by the phrase "low man on the totem pole." A recent report stated that "[r]esearch literature on Indian education forms a dismal, composite portrait of failure upon failure. . . "12 This statement is applicable to many other aspects of Indian life: "The American Indian population is rural, poor, and essentially outside of the mainstream of the larger society."13 Compounding the tragedy of the Indians' economic plight has been their exploitation, often blatant, by the white man. ${ }^{14}$

Although official government policy often has been honorable, Indians seldom have benefited from the noble proclamations. Even though the Northwest Ordinance of $1787^{15}$ provided that "[t]he utmost good faith shall always be observed towards the Indians [and] their land and property shall never be taken from them without their consent . . ., " today the Indians' land holdings are but a pitiful remainder of what they once were. Not only has the acreage been greatly reduced, but much of what Indians still hold has never been more than marginally useful, having been originally selected from land the white man did not want. ${ }^{16}$

Although the federal government recognizes that it has a special responsibility to the Indians because of their exploitation during the United States' territorial expansion, numerous legislative efforts to fulfill this duty have been unsuccessful. ${ }^{17}$ The statutes most relevant to the concerns of this Comment provide Indians with federally protected land that typically cannot be transferred or encumbered without the consent of the Secretary of Interior and that enjoys immunity from taxation, either by express exemption or by judicial construction. ${ }^{18}$ These

12. Subcomm. on Indian Education of the Sen. Comm. on Labor and Public Welfare, The Education of American Indians, Field Investigation and Research Reports, 91st Cong., 1st Sess. 35 (Comm. Print 1969) [hereinafter cited as Field Investigation].

13. Johnson, supra note 2 , at 19.

14. D.M. MCNicol, supra note 1, at 205-44; Collier, supra note 1, at 140-45; Kelly, supra note 1, at 561, 564-65, 572. See also Williams v. Lee, 358 U.S. 217, 218 (1959); United States y. Thurston County, 143 F. 287, 289 (8th Cir. 1906).

15. Ordinance of 1787: The Northwest Territorial Government (July 13, 1787), printed in Organic Laws of the United States, Vol. 1 U.S.C. Xxv, at xxxvii (1964). supra.

16. See A National Tragedy 9. See generally the sources cited notes 5, 14

17. See Bennett, supra note 2, at 659. See also A National Tragedy 9-21; Kelly, supra note 1, at 564-66, 569-73; Comment, supra note 5, at 455-61.

18. For express statutory exemptions, see 25 U.S.C. $\$ 412 a$ (1964) (exempting homesteads purchased from trust funds or restricted funds); Act of May 10, 1928, ch. 
protections were granted in order to avoid the dangers threatening unrestricted Indian land in a competitive and often hostile society and to help Indians attain a living standard cominensurate with that of the general population by providing them with a protected base for economic development. ${ }^{19}$ This Comment argues that such a federal goal can be achieved only if the scope and validity of other Indian-related taxes are also determined according to their effect on the value of the protected land, and that these legislative attempts therefore cannot succeed unless all other taxes which decrease the value of exempt Indian land are eliminated or held not applicable to Indian-related property. This reasoning has often been ignored, and courts have attempted to solve Indian tax problems by using concepts generally appropriate in non-Indian cases. As one of its purposes, this Comment analyzes the taxes involved in some of these cases in order to determime whether they should properly be assessed against the Indian-related property or activity in light of the underlying federal commitment to Indian economic development.

\section{B. Tribal Sovereignty}

Recoguition of Indian tribal sovereignty is based on the original relationship between the tribes and the United States. The Indian tribes were sovereign nations compelled by conquest and treaty to rehin-

517, 45 Stat. 495 (extending period of restriction in lands of certain members of the Five Civilized Tribes); Act of April 26, 1906, ch. 1876, 34 Stat. 137 (providing for the final disposition of the affairs of the Five Civilized Tribes in the Indian Territory); Act of June 30, 1902, ch. 1323, § 2, 32 Stat. 500 (providing for the allotment of certain land to the Creek tribe); Act of July 1, 1902, ch. 1362, 32 Stat. 657 (exempting white settlers who had settled on the land prior to the order from an executive order which extended the boundaries of the Navajo Reservation, Territory of Arizona, so that the settlers were able to retain the land); General Allotment Act of 1887, 25 U.S.C. $\S 331$ (1964) (providing for the allotment of lands in scveralty to Indians on "the various reservations," and extending the protection of the laws of the United States and the Territories over the Indians). For exemptions which were inferred from statutes, see, e.g., Squire v. Capoeman, 351 U.S. 1 (1956) [discussed in the text accompanying notes $41-44$ infra] and Kirkwood v. Arenas, 243 F.2d 863 (9th Cir. 1957) [discussed in the text accompanying note 160 infra].

19. See Squire v. Capoeman, 351 U.S. 1 (1956) [discussed in text accompanying notes 41-48 infra], which stated that the land's special status was intended to protect the Indians' interests and to prepare them to take their place as independent, qualified citizens within society by providing financial advantages [id. at 9]; United States v. Rickert, 188 U.S. 432, 438-43 (1903), which exempted personal property from state taxation because it had been provided by the federal government to be used on protected Indian land and because to tax the personal property would diminish the land's effectiveness in accomplishing its federal purpose; Big Eagle v. United States, 300 F.2d 765, 771-72 (Ct. Cl. 1962) [discussed in note 107 infra], holding that the royalty income from tribal mineral deposits was exempt from federal income tax because the purpose of the General Allotment Act [25 U.S.C. \$§ 331 et seq. (1964)] and the Osage Allotment Act [Act of June 28, 1906, ch. 3572, 34 Stat. 539] was to protect the property to serve the needs of the ward and bring him to a state of 
quish their independence to the federal government. As separate nations within the United States the tribes remained sovereign of the territorial and state governments in which they were located and were subject only to the power of the national government. ${ }^{20}$

This doctrine of strict tribal sovereignty gave the tribes independence from state government and was consistent on the federal level with the guardian-ward relationship which developed as a result of the federal government's assumption of responsibility for the Indians' well-being. Simce the Indians relied substantially on the federal government and made few claims upon the states, the states had no legitimate basis for asserting power over tribal affairs. However, with the development of the federal policy of teaching Indians responsibility by burdening thein with the obhigations of citizenship, ${ }^{21}$ state jurisdiction over Indians expanded.

Although federal policy no longer aims at severing Indians from governmental assistance, Congress has increasingly subjected Indian tribes to state laws. ${ }^{22}$ Despite this trend, lowever, one important limitation on the states' authority over Indians remains: Unless jurisdiction

competency; Sohol v. Clark, - Wash. 2d -, 479 P.2d 925, 929 (1971) [discussed in note 93 infra]. See also Snohomish County v. Seattle Disposal Co., 70 Wash. 2d 668, 425 P.2d 22, cert. denied, 389 U.S. 1016 (1967), in which the Washington supreme court ruled that a county could not require a non-Indian company to obtaiu a garbage permit for activity occurring on protected land within an Indian reservation because a prohibition or limitation on the land's use for commercial purposes would diminish its value, thereby illegally interfering with the land's federal purpose. Id. at $673-74,425$ P.2d at 26.

20. See Williams v. Lee, 358 U.S. 217, 223 (1959); The Kansas Indians, 72 U.S. (5 Wall.) 737, 755-56 (1866); Arizona ex rel. Merrill v. Turtle, 413 F.2d 683, 684-86 (9th Cir. 1969). Contra, McClanahan v. State Tax Comın'n, No. 4370 (Ariz. Sup. Ct., Apache County, Oct. 16, 1969), reprinted in 2 AM. INDIAN NewSLETTER 281 (1969). The erroneous reasoning of McClanahan is discussed in note 121 infra. See also Comment, supra note 5, at 452-54, 472-80; Note, The Indian: The Forgotten American, 81 HaRv. L. REv. 1818, 1820-22 (1968).

21. Kelly, supra note 1, at 559; Act of Aug. 15, 1953, ch. 505, 67 Stat. 588, 589, as amended, Act of Aug. 24, 1954, ch. 910, 68 Stat. 795; Act of Aug. 8, 1958, 72 Stat: 545, amending 18 U.S.C. $\$ \$ 1151,1162,28$ U.S.C. $\$ \$ 1331,1360$ (granting certain states and territories the same civil and criminal jurisdiction, with certain exceptions, over Indian country as they possessed over the rest of the state or territory). For a more complete discussion of Public Law 280, see text accompanying notes 27-33 infra. Pursuant to the termination movennent [discussed in text accoinpanying notes 37-39 infra], Congress passed a series of acts that provided for the withdrawal of all federal services and einployees of the Bureau of Indian Affairs upon completion of plans for termination of the Indian reservation. E.g., 25 U.S.C. $\$ \S 8$ 891-901 (1964) (Menominee); 25 U.S.C. $\$ \$ 564-64 x$ (1964) (Klamath); 25 U.S.C. $\$ 721$ (1964) (Texas tribes); 25 U.S.C. $\$ \$ 741-60$ (1964) (Paiute).

22. E.g., 25 U.S.C. \& 231 (1964) (allowing states, pursuant to rules of the Secretary of Interior, to enter Indian lands for health and educational purposes, except that certain tribes are exempt unless they authorize such action); 25 U.S.C. $\S 349$ (1964) (subjecting Indians, upon expiration of a trust period, to state civil and criminal laws). 
is expressly granted by the federal government, it is denied to the states in all matters that would interfere with a tribe's self-government. ${ }^{23}$

Although courts generally have not analyzed Indian tax cases in terms of the tribal-sovereignty doctrine, the unique legal relationship between the federal government and many Indian tribes should be a second source of tax exemptions for property and activity located within a tribe's jurisdiction. The tribe's sovereignty from state control should preclude the state from imposing taxes on Indians and their property when they are within a tribe's jurisdiction:

To the extent that Indians and Indian property within an Indian reservation are not subject to State laws by reason of Federal limitations, they also may not be subject to State tax laws. ${ }^{24}$

Since this exclusion exists in order to prevent state intermeddling within the jurisdiction of a sovereign tribe, ${ }^{25}$ the property and activity of non-Indians which is located within such a tribe's jurisdiction should also be exempt from state taxes. ${ }^{26}$ A second purpose of this Comment is to determme the circumstances in which the tribal-sovereignty theory should require Indian tax exemptions by analyzing the effect of Indian-related taxes on tribal self-government.

\section{Effect of Public Law 280}

In 1953 Congress enacted Public Law 280, granting certain states and territories ${ }^{27}$ the same civil ${ }^{28}$ and criminal ${ }^{28}$ jurisdiction over Indian country as they possessed over the rest of the state or territory. How-

23. See cases cited note 20 supra and accompanying text. See also Maryland Cas. Co. v. Citizens Nat'l Bank, 361 F.2d 517, 520 (5th Cir. 1966):

The paramount authority of the federal government over Indian tribes and Indians is derived from the Constitution, and Congress has the power and the duty to enact legislation for their protection as wards of the United States.

This protective relationship has been expanded by the courts [see Comment, supra note 5, at 449-50], so that the federal government may be held to a fiduciary duty. Navajo Tribe of Indians v. Umited States, 364 F.2d 320, 322-23 (Ct. Cl. 1966).

24. U.S. Dep'T OF INTERIOR, FEDERAL INDIAN LAW 845 (1958) [hereinafter cited as Federal INDIAN LAW], citing Surplus Trading Co. v. Cook, 281 U.S. 647, 651 (1930).

25. The power to tax is an attribnte of sovereignty. McCulloch v. Maryland, 17 U.S. (4 Wheat.) $316,428-29$ (1819).

26. See text accompanying notes 60-101 infra (personal property exemptions), 111-12 infra (mcome tax exemptions), 155-63 infra (death tax exemptions), 172-85 infra (possessory interest tax exemptions), 186-96 infra (sales tax exemptions).

27. Included were Alaska, which was a territory at the time of the statute's passage, California, Minnesota (except the Red Lake Reservation), Nebraska, Oregon (except the Warm Springs Reservation), and Wisconsin. 28 U.S.C. $\$ 1360$ (a) (1964) (granting civil jurisdiction); 18 U.S.C. $\$ 1162$ (1964) (granting criminal jurisdiction).

28. 28 U.S.C. $\$ 1360$ (1964).

29. 18 U.S.C. $\S 1162$ (1964). 
ever, an exception to the extended jurisdiction is provided:

(b) Nothing in this section shall authorize the alienation, encumberance, or taxation of any real or personal property, including water rights, belonging to any Indian or any Indian tribe, band, or commumty that is held in trust by the United States or is subject to a restriction against alienation imposed by the United States; or shall authorize regulation of the use of such property in a nlanner inconsistent with any Federal treaty, agreenient, or statute or with any regulation made pursuant thereto; or shall confer jurisdiction upon the State to adjudicate, in probate proceedings or otherwise, the ownership or right to possession of such property or any interest therein. ${ }^{30}$

This clause clearly expresses Congress' intent that Public Law 280 should not expand state taxation of trust or restricted Indian real or personal property. Since the purpose of many Indian tax privileges is either to maximize the value of Indian property in fulfillment of the commitment to economic development or to recognize tribal sovereignty, Public Law 280 should not be read to expand state power over other Indian-related tax exemptions; to do so would be inconsistent with federal policy. ${ }^{31}$ This interpretation received strong support from the suggestion by the Ninth Circuit in Kirkwood v. Arenas ${ }^{32}$ that Public Law 280 should have no effect on Indian-related exemptions, whether they exist to further the protected-land purpose or as a result of the tribal-sovereignty doctrine, because the part of the Act quoted above "is entirely consistent with, and in effect is a reaffirmation of, the law as it stood prior to its enactment." ${ }^{\text {33 }}$

30. 28 U.S.C. $\$ 1360$ (b) (1964).

31. See text accompanying notes 111-22 infra (income tax exemptions), 155-63 infra (death tax exemptions), 172-85 infra (possessory interest tax exeinptions), 186-96 infra (sales tax exemptions). But see Note, State Taxation on Indian Reservations, 1966 UTAH L. REv. 132, 146, in which the author infers froin the statute's express exclusion of trust and restricted property an implied grant to the listed states of the power to tax all other Indian property.

32. 243 F.2d 863 (9th Cir. 1957).

33. Id. at 865-66.

Recent cases generally have refused to accept the claims that specific Indians are no longer in need of special protection or that Indians are receiving state assistance as a basis for allowing state taxation of property or activity which otherwise is entitled to federal tax protection. In a federal income tax context the Tenth Circuit has said that the argument that the individual Indian no longer needed the special aid was of no avail; only Congress could alter established federal Indian policy. United States v. Daney, 370 F.2d 791, 795 (10th Cir. 1966). See also Sohol v. Clark, - Wash. 2d -, 479 P.2d 925, 929 (1971) [discussed in note 93 infra]. In Snohomish County v. Seattle Disposal Co., 70 Wash. 2d 668, 425 P.2d 22, cert. denied, 389 U.S. 1016 (1967), the Washington suprenie court was faced with the argument that the owners of adjoining lands were denied equal protection of the laws by virtue of the special treatment of Indian land, but the court said:

We have already determined that this state has no jurisdiction to control either directly or indirectly the use of the Indian lands in question. Where there is no jurisdiction, there can be no denial of equal protection. 


\section{Basic Policy: The Real Property Tax Exemption}

\section{A. The Purpose}

Land has special cultural and economic value to the American Indian. Despite the Indian's decreased dependence on hunting, and despite the efforts which have been made to assimilate Indians into white society, this unique importance of land to Indians continues:

Land is the Indian's prime asset and a major source of income. Real property means more than simply wealth, however. Unlike other minority groups, the Indian's relation to his land is unique; his race, even today, remains extraordinarily dependent upon and imvolved with his natural surroundings. . . . Indian culture has a tradition of naturalistic religion, often rooted in particular tracts. Tribal customs and folkways are also peculiarly associated with historical and territorial values. "Without a land base, Indians will soon cease as a distinct culture." 34

The federal government has recognized the Indians' traditional dependence. upon the land and has souglit to fulfill its obligation to the Indians in treaties and statutes by setting aside land to serve as the foundation for the Indians' development. Under these treaties and statutes the land's legal title is typically held in trust by the Secretary of Interior

Id. at $673-74,425$ P.2d at 27.

Further supporting this position is the federal subsidization of much state aid. In addition to federal programs benefiting the general population are those directed towards Indians. P.L. 81-874, 20 U.S.C. \& 237 (1964) (maintenance subsidy), and P.L. 81-815, 20 U.S.C. $\S \S 631-45$ (1964) (construction subsidy), make funds available to aid state school districts containing federally tax-exempt lands. The Department of Health, Education, and Welfare estimated that in fiscal year 1970, $\$ 19,718,000$ went to the states pursuant to the legislation because of clains against Indian properties. Letter from David V. Dukes, Director, Division of Operations Analysis, to the author, April 5, 1971. 25 U.S.C. \& 309 (1964) authorizes Department of Interior assistance for vocational training for Indians. The Johnson-O'Malley Act, 25 U.S.C. $\$ \S 452-55$ (1964) provides financial aid to Indians through the states, political subdivisions thereof, state universities and schools, and appropriate state and private corporations, for their educational, medical, agricultural, and social welfare. 42 U.S.C. $\$ \S 2001-05(f)$ (1964) provide for federal health assistance for Indians, $\$ 143,096,000$ being allocated for fiscal year 1971. Letter from David V. Dukes, supra.

It can also be said that the states containing the most Indian land, and hence the most tax-exeinpt Indian property, are those most in debt to the Indians for the land that was taken from thein [see text accompanying notes 14, 16 supra, note 32 infra, and sources cited therein], and therefore should bear a larger portion of the cost of helping Indians attain an equal position in society. But see McClanahan v. State Tax Comm'n, No. 4370 (Ariz. Sup. Ct., Apache County, Oct. 16, 1969), reprinted in 2 AM. INDIAN NEWSLETTER 281 (1969) [discussed in note 121 infra], in which the court took judicial notice of the cost incurred by the local county for the Indians in deciding that the state could tax income earned on a Navajo reservation by a Navajo.

34. Comment, supra note 3 , at 101. 
for the Indian beneficiary or held by the Indian owner subject to restrictions on alienation. In either case the Secretary of Interior's approval is necessary for the land's sale or transfer in order to assure its continued use for the Indians' benefit. 35 In addition to providing that the land be held in trust or under restriction, many of the statutes and treaties exempted the land from taxation, which thereby greatly increased its value to the Indian owner. ${ }^{36}$

The necessity of such protection for poor and uneducated Indians was forcefully demonstrated by the great losses of land that resulted from the termination of many federal protections subsequent to the 1953 passage of House Concurrent Resolution No. 108.37 Many educationally unsophisticated Indians lost their land to white businessmen, and many of the poor lost their land in tax sales because of the legislation following the resolution, which declared:

[I]t is the policy of Congress, as rapidly as possible, to make the Indians within the territorial limits of the United States subject to the same laws and entitled to the same privileges and responsibilties as are applicable to other citizens of the Umited States, to end their status as wards of the United States, and to grant them all the rights and prerogatives pertaining to American citizenship..$^{38}$

The consequent erosion of Indian well-being was so startling that in 1959 the Commission of the Bureau of Indian Affairs "clarified" the Department of Interior's interpretation of Concurrent Resolution No. 108 , stating in his annual report that "it would be incredible, even criminal, to send any tribe out into the mainstream of American life until and unless the educational level of that tribe was one which was equal to the responsibilities which it was shouldering." ${ }^{\text {99 }}$

35. See, e.g., 25 U.S.C. $\$ 392$ (1964).

36. See note 18 supra. These statutory exemptions can be retracted by subsequent statutes [The Cherokee Tobacco, 78 U.S. (11 Wall.) 616, 620-21 (1870)], as can exemptions which were granted by treaties:

The Tribes have been regarded as dependent nations, and treaties with them have been looked upon not as contracts, but as public laws which could be abrogated at will by the United States.

Choate v. Trapp, 224 U.S. 665, 671 (1912). This general rule does not hold if the exemption was granted to the Indians as part of a bargained-for exchange, in which case it is a vested right that enioys the same constitutional protection as other property. However, the extent of such an exemption, including its alienability, is subject to the terms of the agreement in which it was received. Also, if it was received as consideration in an agreement it is subject to divestiture by agreement and can be traded to the government for another benefit. Sweet v. Schock, 245 U.S. 192, 197 (1917). See generally Note, supra note 31.

37. H.R. Con. Res. 108, Aug. 1, 1953, 67 Stat. B132. For examples of termination legislation see note 21 supra. For a discussion of some of the tragic land losses resulting from such legislation, see The EduCATION of AMERICAN INDIANs, supra note 3, at 36; Kelly, supra note 1, at 564, 571.

38. H.R. Con. Res. 108, Aug. 1, 1953, 67 Stat. B132.

39. 1959 SEC. OF THE INTERIOR ANN. REP. 231. In response to a letter from 


\section{B. Exemptions: Express and Implied}

The tax exemptions which are derived from the acts and treaties are implied as well as express. There is no controversy concerning the express exemptions, but a court's willingness to find an implied exeinption usually depends upon whether it looks to the policies underlying the protected status of Indian land. Thus, a court ordimarily will find the land exempt if it recognizes the restrictions on alienation as evidence of the "federal pohicy . . . to encourage the tribal Indians to becoune self-sufficient in the development and commercial use of resources of the reservation," ${ }^{40}$ as well as to maximize the value of Indian land generally.

In Squire v. Capoeman ${ }^{41}$ the United States Supreme Court focused on the purpose of the Indian land's protected status when it held that the proceeds from a sale of standing timber growing on trust land allotted to Indians pursuant to the General Allotment $\mathrm{Act}^{42}$ were not subject to federal income taxation. The Court relied on the Act's purpose of preserving the land's value for the Indian owners, which could be achieved only if the proceeds of the sale were exempt, because the land's value was embodied primarily in the timber:

The wisdom of the congressional exemption from tax embodied in Section 6 of the General Allotment Act ${ }^{43}$ is manifcsted by the facts of the instant case. Respondent's timber constitutes the major value of his allotted land. The government determines the conditions under which the cutting is made. Once logged off, the land is of little value. The land no longer serves the purpose for which it was by treaty set aside to his ancestors, and for which it was allotted to him. It can no longer be adequate to his needs and serve the purpose of bringing him finally to a state of competency and independence. Unless the pro-

the Association on American Indian Affairs, Inc., stating its belief that the resolution was a dead letter, Secretary of Interior Udall stated: "I most certainly agree that resolution, whatever it means, died with the 83d Congress and is of no legal effect at the present time." Letter from Stewart L. Udall to Richard Schifter, April 15, 1961. See also 7 Cannon's Precedents of the House of Representatives of the UNITED States \& 1037, at 150 (1935) ("A concurrent resolution is without force and effect beyond the confines of the Capitol").

40. Donahue v. California Justice Court, 15 Cal. App. 3d 557, 93 Cal. Rptr. 310 (1st Dist. 1971).

41. 351 U.S. 1 (1956).

42. 25 U.S.C. $\$ \S 331$ et seq. (1964).

43. 25 U.S.C. $\$ 349$ (1964):

[T]he Secretary of the Interior may, in his discretion, and he is authorized, whenever he shall be satisfied that any Indian allottee is competent and capable of managing his or her affairs at any time to cause to be issued to such allottee a patent in fee simple, and thereafter all restrictions as to sale, incumbrance, or taxation of said land shall be removed and said land shall not be liable to the satisfaction of any debt contracted prior to the issuing of such patent.... 
ceeds of the timber sale are preserved for respondent, he cannot go forward when declared competent with the necessary chance of economic survival in competition with others. This chance is guaranteed by the tax exemption afforded by the General Allotment Act, and the solemn undertaking in the patent. It is unreasonable to infer that, in enacting the income tax law, Congress intended to limit or undermine the Government's undertaking. To tax respondent under these circumstances would, in the words of the court below, be "at the least, a sorry breach of faith with these Indians." 44

A related case that provides further evidence of some courts' willingness to look to the intended function of express Indian tax immunities is Shepard $v$. United States, ${ }^{45}$ which held that, when the restriction has ended and the land is sold by its Indian owner, the basis of the property for the computation of capital gains tax should be determined as of the date of the exemption's termination, and nut as of the property's acquisition. ${ }^{40}$ Though the land could be taxed after the termination, the court ruled that "when the government's fiduciary undertaking to its Indian wards, set out in treaties, statutes, and case law, is remembered," 47 to set the basis as of the date of the original allotment would be inconsistent with the Act's purpose of maximizing the land's value to the Indian owner. By looking to the underlying policies, both Squire and Shepard firmly establish that federal tax exemptions are intended to maximize the value of protected Indian land and thereby facilitate economic development. ${ }^{48}$

\section{Terminating Exemptions}

Tax exemptions usually terminate with the expiration of the land's restricted or trust status, which occurs when the Secretary of the Interior

44. 351 U.S. at 10.

45. 162 F. Supp. 313 (E.D. Wis. 1958).

46. The court rehed on Squire v. Capoeman, 351 U.S. 1 (1956), but, instead of referring to section 6 of the General Allotment Act, it cited a section providing that at the end of the restricted period the fee should be transferred to the allottee "free of all charge or incumbrance." 25 U.S.C. $\$ 348$ (1964), cited in 162 F. Supp. at 315.

47. 162 F. Supp. at 315 .

48. Another case which states clearly that the land's immunity from direct taxation is indicative of the congressional goal to provide Indians a protected economic base is Big Eagle v. United States, 300 F.2d 765 (Ct. Cl. 1966), which held that trust imcome earned from exempt land was exempt from federal taxation because Congress' purpose was "to protect the property so that it will adequately serve the needs of the ward and finally bring him to a state of competency and independence. This chance is encouraged, if not guaranteed, by tax exemption." Id. at 771-72.

An earlier case dealing with an attempted county taxation of trust land used the tribal-sovereignty doctrine to void the tax: In The Kansas Indians, 72 U.S. (5 Wall.) 737 (1867), the county conceded that the land held in common was not taxable, but contested the claimed exemption for the land held in severalty. In answer the Supreme Court pointed out that the treaty (Treaty of Aug. 8, 1831, 7 Stat. 355) did not distinguish between the two types of land, stating: 
considers the Indian owner to be intellectually competent to control his land. ${ }^{49}$ However, since the restriction and exemption existed because the Indian needed and deserved economic aid as well as managerial assistance, ${ }^{50}$ conditioning the exemption on continuation of the restriction or trust may result in premature terminations to Indians intellectually but not economically "competent."

Congress should allow the Secretary of the Interior to terminate the tax exemption and the restriction on alienation independently. The land restrictions would still be lifted when the Indian is judged ready to profit from the experience of controlling his property, ${ }^{51}$ but before removing the exemption the Secretary would consider the Indian's financial ability to pay taxes as well as his need for the economic benefits that accrue to the tax exemption, including the land's potentially higher rental value. ${ }^{52}$

Under this proposal the land's immunity would also be lost when the land is transfered to someone other than a protected Indian, that is, to someone not entitled to an exemption. ${ }^{53}$ Although the Indian vendor could receive more for the land if the exemption were also transferable, the federal policy encouraging Indians to build upon a land base is furthered if the Indian is encouraged to hold the land. This rule would provide such an incentive because the land would not be sold unless the consideration received was adequate compensation for the value of the lost tax exemption in addition to the value of the land itself. Moreover, this rule would prevent a restriction from indefinitely running with the

If the tribal organization of the Shawnees is preserved intact, and recognized by the political department of the government as existing, then they are a "people distinct from others," capable of making treaties, separated from the jurisdiction of Kansas, and to be governed exclusively by the government of the Union. ... "[U]ntil they are clothed with the rights and bound to all the duties of citizens," they enjoy the privilege of total immunity from state taxation.

Id. at $755-56$

While the general government has a superintending care over their interests, and continues to treat with them as a nation, the state of Kansas is estopped from denying their title to it. ... Conferring rights and privileges on these Indians cannot affect their situation, which ean only be changed by treaty stipulation, or a voluntary abandoninent of their tribal organization. Id. at 757 .

49. E.g., 25 U.S.C. $\$ 349$ (1964). Cf. Choteau v. Burnet, 283 U.S. 691, 694-95 (1931).

50. See text accompanying notes 12-14 supra and sources cited therein.

51. As suggested by a former Commissioner of Indian Affairs, the Indian should be exposed to the responsibilities of land ownership gradually. F. LEUPP, THE INDIAN AND His ProBLEM 69-78 (1910). Others have advocated a more sudden approach, often with tragic results. See Kelly, supra note 1, at 569-73.

52. See text accompanying notes 55-59 infra.

53. If the land's alienation were still restricted the Secretary's approval of the sale would be necessary. Otherwise the competency established in removing the restriction would be evidence of the Indian's ability to make such a decision. 
land unless the owner was a protected Indian, a condition that would probably be necessary for such a proposal to get the necessary political support. ${ }^{54}$

\section{Implications of the Real Property Exemption}

Much Indian economic progress can be achieved by the profitable utilization of his land, as has been demonstrated in the past:

[T]he picture is not dark for all Indians or in all places. Some tribes have demonstrated that Indians can be enterprising and successful. They have converted some of their lands into profitable uses, lured industry to their areas, supplied a stable local labor force 一and prospered. ${ }^{55}$

Development of the land is also desirable because of the Indian's ties to it:

Indians attach a great social and symbohic significane to their land and, almost universally choose to remain on their land as self-employed farmers or livestock growers until economic necessity forces them to

54. If the immunity is limited to land that was, or is, protected, there will be no reduction of land available to state or local government for taxation. Instead, the amount of exempt land would decrease as it is sold to unprotected persons and as the Secretary determines that the immunity is no longer needed. See Fink v. Board of County Comm'rs, 248 U.S. 399, 404 (1919), in which the Supreme Court ruled that tax-exempt land loses its immunity wheu sold by its protected Indian owner. However, land located within a reservation which is sold to a non-Indian should regain its exemption if reacquired by a protected Indian, since it had never really lost its characterization as Indian land. Cf. Seymour v. Superintendent, 368 U.S. 351 (1962) (non-Indian-owned land within a reservation is treated as part of the reservation for criminal jurisdiction purposes); Buster v. Wright, 135 F. 947 (8th Cir. 1905), appeal dismissed, 203 U.S. 599 (1906) (a tribe can tax land owned by a non-Indian which is within the boundaries of its reservation); Kain v. Wilson, 83 S.D. 482,161 N.W.2d 704 (1968) (non-Indian-owned land within a reservation is treated as part of the reservation for civil jurisdiction purposes, so the state did not have jurisdiction to hear an action by the non-Indian owner against a tribal Indian).

Even limiting immunity to land that was specifically granted an exemption by a statute or treaty would be a compromise with logic. Land purchased by an Indian with protected or trust funds should also be tax-exempt if land ownership is to be encouraged, but the approach of limiting the immunity to land expressly exempted by statute would render land purchased with such funds taxable. Some courts have implied that the protected status should continue even though the property is converted into another form. See United States v. Board of County Comm'rs, 154 F.2d 600, 605 (10th Cir. 1946); National Bank of Commerce v. Anderson, 147 F. 87, 90 (9th Cir. 1906); United States v. Thurston County, 143 F. 287, 290-92 (8th Cir. 1906). Other courts, probably concerned with local governments' pressing need for tax revenue [see Note, supra note 31 , at 137], have taken the position that only the original property itself is exempt. See Shaw v. Gibson-Zahniser Oil Corp., 276 U.S. 575, 580-81 (1928); United States v. Mummert, 15 F.2d 926, 928-29 (8th Cir. 1926); United States v. Gray, 284 F. 103, 105-06 (8th Cir. 1922). For a discussion of this latter rule's weakness, see FEDERAI INDIAN LAW 860-64.

55. Johnson, supra note 2 , at 35 . 
abandon agriculture or supplement imcome from this source through seasonal or temporary wage work. ${ }^{56}$

However, it seems evident that incentives are necessary to attract desirable businesses because of the many inherent disadvantages of Indian land. Thus, the Bureau of Indian Affairs' attempts to attract light industry plants to reservation sites have met with only limited success because most Indian land is far from major markets and there is "no social base for well-developed utilities and facilities, such as electric power, water, good roads, and the like . . .."57 In addition, there is the difficulty of having to deal with the distant and bureaucratic offices of the federal government that is necessary if the land is held in trust or under restrictions. ${ }^{\overline{8}}$

Real property tax immunity can serve as a means of overcoming many of these difficulties by providing an important economic imcentive for land utilization. However, the immunity's purpose of maximizing the value of the protected land to its Indian owner can be achieved only if the land is immune from all other taxes which adversely affect its value. The real property tax exemption therefore provides a strong basis for striking down taxes on personal property, income, estates, possessory interests, and sales that defeat the purpose of the basic immunity. ${ }^{59}$

\section{III}

\section{Specific Taxes ReEXamined}

\section{A. Personal Property Tax Exemption: Protecting Federal Policy}

\section{The Instrumentality Doctrine}

The instrumentality doctrine protects against interference with federal policy by state and local taxation. Rooted in Justice Marshall's often quoted declaration that "the power of taxing [a federal instrumentality] by the states may be exercised so as to destroy it,"60 the instrumentality doctrine evolved as a means of preventing the taxation, and potential control of one government's functions by another. ${ }^{01}$ Instrumentalities of governmental policy, such as some lessees of federal land, ${ }^{02}$

56. Jenny, supra note 3 , at 50.

57. Id. at 51 .

58. See note 105 infra.

59. See text accompanying, respectively, notes 86-98, 111-20, 155-71, 172-80, 186-92 infra. The tribal-sovereignty doctrine will also invalidate some state and local taxation of Indian-related property and activity. See text accompanying notes 103-06, 182-85 infra.

60. McCulloch v. Maryland, 17 U.S. (4 Wheat.) 316, 427 (1819).

61. See McCulloch v. Maryland, 17 U.S. (4 Wheat.) 316, 429-35 (1819). See also sources cited note 63 infra.

62. See Gillespie v. Oklahoma, 257 U.S. 501, 505 (1922) and Choctaw, O. \& G. 
were afforded tax immunities because many governmental policies were effectuated through contracts with private parties. ${ }^{63}$

As the instrumentality doctrine expanded, subsequent courts reacted to the fear that local governments were being deprived of too much tax revenue, ${ }^{84}$ and they attempted to establish a test that would balance the conflicting interests of governmental sovereignty and the states' power of taxation. ${ }^{65}$ One solution was to distinguish an instrumentality's governmental function from its property, exempting only the former on the theory that this would sufficiently protect against interference with federal policy. ${ }^{66}$ Most courts have followed this distinction, with the result that some taxes on property have been upheld even though they imposed a financial burden on the governmental instrumentality or on the government itself. ${ }^{67}$ These decisions did not deny that taxes that directly interfere with governmental functions are illegal; in effect they ruled that the imposition of a pure financial burden on the federal government or its agent is generally too remote an interference with the governmental policy to be invalid. ${ }^{68}$

R.R. v. Harrison, 235 U.S. 292, 298 (1914), in which lessees of land held in trust for Indian beneficiaries were exempted from state taxation because of their role in helping the United States fulfill its obligation to Indians. These cases were subseqnently overruled in Helvering v. Mountain Producers Corp., 303 U.S. 376, 390 (1938), and Oklahoina Tax Comm'n v. Texas Co., 336 U.S. 342, 365 (1949), respectively. See text accoinpanying notes 75, 114 infra.

63. For a discussion of the decline of instrunentahty imununities, see Powell, The Waning of Intergovernmental Tax Immunities, 58 HARV. L. REv. 633 (1945); Powell, The Remnant of Intergovernmental Tax Immunities, 58 HARv. L. REv. 757 (1945).

64. See Note, supra note 31 , at 137.

65. See generally Powell, The Waning of Intergovernmental Tax Immunities, supra note 63, at 646-62; Powell, The Remnant of Intergovernmental Tax Immunities, supra note 63 , at $758-75$.

66. See Eastern Air Transport, Inc. v. South Carolina Tax Comm'n, 285 U.S. 147, 152-53 (1932); Alward v. Johnson, 282 U.S. 509, 514 (1931); Thomson v. Pacific R.R., 76 U.S. (9 Wall.) 579, 590-91 (1870). The courts believed that since the governmental function in each of these cases was to sponsor a particular activity and not to raise inoney, the property tax was only indirect interference; therefore, the need for state revenue was predominant. This reasoning is not justified in Indian cases, however, because there the federal interest is directly damaged if the value of exempt Indian land decreases. Indian cases are unique in that the federal interest is primarily of a financial nature, whereas in most relationships with instrumentalities it is not. See text accompanying notes 86-98 infra.

67. E.g., Alabama v. King \& Boozer, 314 U.S. 1(1941) (upholding a sales tax on building materials bought for use in performing a cost-plus Government contract). See also United States v. Detroit, 355 U.S. 466 (1958) (upholding a tax on a lessee's business conducted on tax-exempt United States land, even though the taxes paid were deductible from the rent); Oklahouna Tax Comm'n v. Texas Co., 336 U.S. 342 (1948) (holding a lessee of mineral rights on restricted Indian land liable to nondiscriminatory state gross production and excise taxes); Taber v. Indian Terr. Illuminating Co., 300 U.S. 1 (1937) (upholding a nondiscriminatory state ad valoren tax on equipment used by a private corporation operating for oil on restricted Indian land).

68. See, e.g., Taber v. Indian Terr. Illummating Co., 300 U.S. 1, $3-4$ (1936). 
Implicit in this characterization is the view that the government has neither a financial interest in its instrumentality nor an interest in affording the private agency an economic benefit greater than that necessary to induce it to perform the activity. Thus, in Graves v. New York ex rel. O'Keefe, ${ }^{69}$ the Supreme Court upheld a state tax on the income of an employee of a wholly owned federal instrumentality:

[T] he purpose of the immunity was not to confer benefits on the employees ... or to give an advantage to a government by enabling it to engage employees at salaries lower than those paid for like services by other employers, public or private, but to prevent undue imterference with the one government by imposing on it the tax burdens on the other. ${ }^{70}$

This reasoning makes a good deal of sense in non-Indian cases; the federal government's intention usually is to have a particular activity performed, and the governmental pohicy does not depend on the enterprise making a profit. ${ }^{71}$ For example, if the federal government contracts to have a crop grown in order to combat a food shortage, taxation of the activity would impede only the secondary goal of minimizing costs, but it would not frustrate the primary goal of having the crop grown unless the tax were so great as to completely prevent the activity. There is ordinarily no need to protect federal policy by invalidating such a tax because the courts can prevent a destructive effect when the situation arises, as Justice Holmes asserted in answer to Justice Marshall: "The power to tax is not the power to destroy while this Court sits." 2

In cases involving Indian interests, however, fundamentally different ground rules apply. The purpose of the federal policy is profitability of the enterprise, and the measure of the federal policy's success is the degree of economic improvement in the Indian's position. Thus, a tax directly interferes with the central policy goal. Unfortunately, however, the early cases whicli struck down Indian-related taxes by using the instrumentality doctrine did not expressly identify the federal pohicy hindered by the tax. An example of this was Choctaw, O. \& G.R.R. v. Harrison, ${ }^{73}$ in which the Supreme Court struck down a county tax imposed on the gross sales of coal dug from mines on trust land by a non-Indian private company, stating that since the company was an in-

69. 306 U.S. 466 (1939).

70. Id. at 483-84.

71. For cases upholding a congressionally provided or implied exemption where profitmaking was essential to the federal function, see Federal Land Bank v. Board of County Comm'rs, 368 U.S. 146, 151-52 (1961) [discussed in text accompanymg note 86 infra] and Federal Land Bank v. Bismarck Lumber Co., 314 U.S. 95, 102-03 (1941) [discussed in note 88 infra].

72. Panhandle Oil Co. v. Mississippi ex rel. Knox, 277 U.S. 218, 223 (1928) (dissenting opinion).

73. 235 U.S. 292 (1914). 
strumentality of the federal government it could not be taxed on the performance of its duty. The Court implied, however, that the tax would have been valid had it been a property tax imposed on the coal when owned by the company, even though located on exempt Indian land, presumably because the instrumentality doctrine does not protect the property of an instrumentality. ${ }^{74}$ The Court failed to observe that, by decreasing the net profits from the mine, the tax interfered with the federal intent that the mine provide a source of income for the Indians' support.

Instead of determining on a case-by-case basis whether the Indianrelated tax threatened an important federal policy, such early decisions relied on instrumentality formulas developed im non-Indian cases im which the success of the federal goal was not seriously endangered by the tax's added cost. The result was that in 1948, in Oklahoma Tax Commission v. Texas Co. ${ }^{75}$ the United States Supreme Court reversed some of its previous decisions ${ }^{76}$ and overruled the Oklahoma supreme court which had invalidated a nondiscriminatory state gross production tax and a state excise tax on petroleum produced from protected Indian land. The Court used a formula derived from cases which did not make clear that state taxes should be avoided only if they interfered with federal policy, ${ }^{77}$ and failed to distinguish cases that blindly relied on the shorthand imstrumentality formulas from those that voided taxes in order to protect national policy. It thus reverted to a formalistic ap-

74. Id. at 299.

75. 336 U.S. 342 (1949).

76. Indian Terr. Illuminating Oil Co. v. Oklahoma, 240 U.S. 522 (1916); Choctaw, O. \& G. R.R. v. Harrison, 235 U.S. 292 (1914).

77. Referring to the rule that a federal instrumentality is not subject to state taxation, the Oklahoma supreme court voided the tax "flatly on the ground that the lessee was an iustrumentality of the Federal Government and as such . . . not subject to the taxes in question" [336 U.S. at 348], without analyzing the tax in terms of its effect on federal policy. Instead, the Oklahoma court should have characterized the mine and its ore rather than the lessee as the instrumentality-if it felt compelled to use intrumentality language-since these were the tools used by the federal government to provide financial aid to the Indians. The lessee would have been the instrumentality only if the government's purpose had been to mine the ore for the sake of the ore itself. For a discussion of Graves v. New York ex rel. O'Keefe, 306 U.S. 466 (1939), see note 69 supra and accompanying text. See also Federal INDIAN LAW 864-66, which resorts to instrumentality language when it states that Indian personal property tax exemptions are implied in order to prevent the taxation of governmental instrumentalities, the personal property being the instrumentality. Significant, however, is the realization that state or local taxes of Indian-related personalty should be voided when they would frustrate federal policy, and that the success of this policy is extremely vulnerable to taxation:

Wherever personal property is acquired by or for tribal Indians for use on Indian reservation lands in connection with or in furtherance of the policy adopted by the Government in encouraging the Indians to cultivate the soil and to establish permanent homes and families, or otherwise aid im their economic rehabilitation, such property may not be taxed by the State. The 
proach, pointing out that the gross production tax had been construed to be a tax on the instrumentality-lessee's property. ${ }^{78}$ Reflecting the concern that instrumentality immumities were becoming too widespread, ${ }^{78}$ the Court then responded to the claim that the taxes interfered with federal policy by referring to cases in which the federal policy was not threatened by the state tax: ${ }^{80}$

[S]o far as concerns private persons claiming immunity for their ordinary business operations (even though in connection with governmental activities), no implied constitutional immunity can rest on merely hypothetical interferences with governmental functions here asserted to sustain exemption. ${ }^{81}$

This statement would have been accurate if the oil well's governmental function had been to providc oil, because that goal probably would not be impeded unless the tax were so prohibitive as to prevent the mining activity altogether. ${ }^{82}$ However, the tax was not a mere "hypothetical interference with governmental function" because whether the tax was levied on governmental property or on the mine operator's property or activity, it reduced the mine's value. Since the well's governmental function was to further the national policy of aiding the Indians' economic development, its decrease in value interfered substantially with federal policy by ultimately reducing the income received by the Indians. ${ }^{83}$

Another case which failed to recognize the unique nature of Indian cases in the area of the instrumentality doctrine is Thomas v. Gay, ${ }^{84}$ which upheld a state tax on a non-Indian's cattle which were grazing on an Indian reservation pursuant to a lease authorized by Congress. The Court ignored the decrease in rental value of the land due to the tax. Instead, it rehed on the rule that a federal instrumentality's property is subject to state taxation, implying that the lessor was the instrumentality: "But it is obvious that a tax put upon the cattle of the lessees is too remote and indirect to be deemed a tax upon the lands or privileges of

immunity exists whether the property be purchased with moneys held in trust by the United States for the Indians or with moneys accruing to the Indians from other Federal sources.

Id. at 864 .

78. 336 U.S. at 346.

79. See note 64 supra and accompanying text.

80. E.g., 336 U.S. at 352-65, citing Helvering v. Mountain Producers Corp., 303 U.S. 376 (1938) (upholding a federal tax on mcome of a private coinpany producing oil from land leased by a state, the state reserving a royalty).

81. 336 U.S. at 365.

82. See note 72 supra and accompanying text.

83. The Indians owned a one-eighth royalty interest [336 U.S. at 345], so their income would decrease with a decrease in the oil extracted. In addition, as the profitability to the lessee decreased he would be willing to pay less rent.

84, 169 U.S. 264 (1898), 
the Indians." remote had it characterized the protected land as the instrumentality and the maximization of its economic value to the Indian owner as the governmental function entitled to exemption. In any event, a bettcr approach would be to determine the tax's legality according to whether or not it threatens federal policy.

Despite its lumping together of Indian-policy cases with more general instrumentality rules, in another context the Supreme Court has indicated that it recognizes the special instrumentality issues involved when dealing with federal functions whose success depends upon profitability, as distinguished from those projects only collaterally interested in financial considerations. In Federal Land Bank v. Board of County Commissioners, ${ }^{86}$ the Court voided a county personal property tax which was imposed on mineral rights owned by the Federal Land Bank. The Court indicated that the tax would have been legal if the Bank's purpose had been to provide a market for governmental bonds or to serve as the federal government's depository and fiscal agent, because the success of those functions would not be endangered by the tax unless it were so large as to completely discourage the activity, in which case the courts could act to reduce the tax. ${ }^{87}$ However, since the Bank's purpose was to provide agricultural loans at low interest rates, which was partially accomplished by distributing profits to its share-

85. Id. at 273. This statement is based on reasoning similar to that behind the rule developed in non-Indian instrumentality cases. See text accompanying notes 60-67 supra. In these cases the federal purposes involved were not financial. Thomas v. Gay cited Adams Express Co. v. Ohio State Auditor, 166 U.S. 185 (1897) and Henderson Bridge Co. v. Kentucky, 166 U.S. 150 (1897), cases concerned with the effect of a state tax on Congress' power to regulate commerce. The cases upholding state taxes whose effect on interstate commerce is only indirect are analogous to Alabaina v. King \& Boozer, 314 U.S. 1 (1941), in which a party contracting to do work for the federal government on a cost-plus basis was held subject to a state sales tax because the federal interest was not primarily economic. See text accompanying notes 67-72 supra. For other examples of cases upholding taxes on the property of a non-Indian located on tax-exempt Indian land, see Taber v. Indian Terr. Illuminating Oil Co., 300 U.S. 1 (1937); The Cherokee Tobacco, 78 U.S. (11 Wall.) 616 (1870). These cases characterized the lessees as the governmental instrumentality because they were allowed to lease the land in order to generate income for the Indian owners, thereby fulfilling the government's obligation to the Indians. The taxes were upheld in reliance on the rule that taxation of an instrumentakity's property is legal, which made the tax status of personal property depend upon the identity of the owner: When the owner was neither the federal government nor a protected Indian, the tax was upheld, even though the personalty was located on tax-exempt Indian land. Instead, the courts should have determined whether the government's goal-providing land whose economic value could be maximized by the Indian owner-would be obstructed by taxing the property. Since the restricted or trust land's rental value was decreased by not immunizing personalty located on it regardless of the owner, the taxes should have been struck down for interfering with federal policy. See text accoinpanying notes $86-98$ infra.

86. 368 U.S. 146 (1961).

87. Id. at 151-52. See also note 72 supra and accompanying text. 
holder-borrowers, any reduction of profits interfered with optimal achievement of the Bank's governmental function. The tax was held invalid even though it was imposed merely on an instrumentality's property, because the federal goal was dependent upon the Federal Land Bank's profits, which the tax reduced. ${ }^{88}$

Federal Indian policy is analogous because it depends upon the maximum profitability of protected Indian land. The Court held in Federal Land Bank that providing low-interest agricultural loans is a governmental activity qualified for immunity from interfering state and 10cal taxation. Providing economic aid to Indians is also a governmental function; in fact, it is uniquely governmental, as has been recognized by those courts that have discussed the United States obligations to the American Indian. ${ }^{89}$ That exempt land is the vehicle used to fulfill these obligations by affording Indians a protected base for economic activity does not lessen the governmental nature of the land's function.

\section{Formulating the Test: Location on Protected Indian Land}

The location of personal property on protected Indian land should serve as both a necessary and sufficient condition for exemption from local taxation. The location requirement is necessary because a test that determines the validity of Indian-related exemptions solely according to the tax's effect on the protected land could have undesirable results. It might, for example, result in an exemption merely because a piece of property is owned by someone who lives on protected Indian land, or by a company based on such land, even though the property is located elsewhere, since this would significantly increase the land's rental value. Similarly, property manufactured on protected land might be provided an exemption that follows it off the land, because such an immumity would have a favorable economic effect on the land's rental value.

Limiting the immunity to personal property located on protected land provides an objective standard for elimimating many such exemptions, which may seem too remote from the purposes of the land's protection to warrant the resulting burden on local taxing entities. ${ }^{00}$ By

88. 368 U.S. at 150. See also Federal Land Bank v. Bismarck Lumber Co., 314 U.S. 95 (1941), in which the Court held that Congress could exempt a purchase by the Federal Land Bank from a state sales tax. In response to the state's argument that Congress could immunize only the bank's activtities as a depository and fiscal agent of the federal government, and not the lending function or activities incidental thereto, the Court said that the bank also performed a governmental function by providing low-interest loans. Since the bank's ability to provide low-interest loans depended on minimization of costs, Congress was constitutionally authorized to immunize the bank from state taxation. Id. at 102-03.

89. See text accompanying notes 17-18 supra and sources cited therein.

90. Note, supra note 31 , at $144-48$. 
eliminating those exemptions the proposed limitation protects local governments' power of taxation by assuring that the personal property be closely related to the Indian land in order for it to be tax-exempt. In this respect the personalty's location is more meaningful than its ownership $^{91}$ or the distinction frequently made between governmental function and purpose..$^{92}$

The personalty's location on protected Indian land should also be a sufficient condition for the exemption, because to tax such property directly frustrates federal policy both by decreasing the land's rental value and by impairing its usefulness to Indian owners who choose to use the land themselves. ${ }^{93}$ Maximum utilization of land frequently requires either the erection of costly improvements or the use of expensive machinery on the land, and the Indians' ability to afford either would be greatly reduced by a tax burden on personal property. This is especially true in the case of an ad valorem tax, which further discourages the use of costly property.

In Makah Indian Tribe v. Clallam County, ${ }^{94}$ the Washington supreme court voided a county-imposed tax on personal property located on a reservation and owned by an Indian and her non-Indian spouse. The court voided the tax because it decreased the land's value and thereby interfered with federal Indian policy, which is uniquely dependent upon fimancial considerations:

The reasons for such a ruling lie almost exclusively in the discern-

91. See note 85 supra.

92. See text accompanying notes 67-68 supra and sources cited therein.

93. See, e.g., Makah Indian Tribe v. Clallam County, 73 Wash. 2d 677, 683, 440 P.2d 442, 446 (1968):

Trust lands, whether held in trust for the tribe as an entity or for tribal Indians individually, are not taxable by the state or its subdivisions. It follows that personalty continuously held, kept, and used exclusively on the reservation is not taxable either unless the Congress decides otherwise, and, therefore, the distinction between the forms of property thus becomes immaterial in this case.

In Sohol v. Clark, - Wash. 2d -, 479 P.2d 925 (1971), the Washington supreme court exempted personal property used in a business located on protected land from state taxation because the court found that the Indian owner was engaged in the business pursuant to a federal program designed to further economic independence among Indians. The program was evidenced by the Indian's purchase of the business with money earned from protected Indian land. "Plaintiff is entitled to all of the foregoing assistance [Bureau of Indian Affairs economic aid] because she is a non-competent tribal Indian. . . . She is the beneficiary of a federal policy designed to encourage non-competent tribal Indians to become economically self-sufficient, whether on ther own] or another reservation." Id. at -, 479 P.2d at 928-29.

The possibility that this exemption could be exploited by moving property onto Indian land merely for the assessment period could be frustrated by conditioning the exemption on the requiremeut that the property be located on the Indian land for a certain percentage of the tax period, or by prorating the tax according to the time the property was within the taxable area.

94. 73 Wash. 2d 677, 440 P.2d 442 (1968). 
able federal policy of encouraging Indians to become economically self-sufficient on their reservations. In some instances, the government even augments the policy by supplying the means. We are simply adapting this policy of encouragement to property acquired by the Indians as the fruits of their own work, labor and enterprise as well as to the property given by the United States in aid of tribal Indians. ${ }^{95}$

The court almost indicated that it regarded the personal property's location on protected Indian land as a sufficient condition for concluding that its exemption was necessary to protect federal policy:

If the . . property . . . were kept, nraintained, and used off the reservation, it would be taxable as personal property even though one spouse was a tribal Indian; when kept, used and nuaintained on the reservation, it was not taxable as personal property by Clallan County, even though one spouse was a non-Indian. ${ }^{96}$

In any event, the court reasoned that property used in business should be exempt because it is as much the government's purpose to foster successful business enterprises on the reservations as it is to encourage farming, ranching, and fishing. ${ }^{.7}$ It follows from similar reasoning that property and equipment located on exempt land for those purposes should receive the tax protection afforded farming equipment, regardless of who owns the property. This reasoning also imdicates that activity occurring on the land should be exempt. ${ }^{98}$

State taxes imposed on property or activity located on protected Indian land cannot be defended upon the ground that they are nondiscriminatory. The commerce clause cases that utilize this approach are inapposite in the present context because of the differing purposes of the interstate commerce and Indian-related exemptions. Whereas the former perform the neutral function of protecting against state-erected impediments to interstate commerce, such as discriminatory taxes or taxes that could be assessed by a number of states, ${ }^{90}$ Indian-related exemptions are intended to confer a positive benefit. ${ }^{100}$ The broader purpose of the Indian-related exemption to assure the success of federal poli-

95. Id. at 685,440 P.2d at 447 (emphasis added).

96. Id.

97. 73 Wash. $2 \mathrm{~d}$ at 686,440 P.2d at 447 , citing United States v. Rickert, 188 U.S. 432 (1903). See also Note, supra note 20, at 1854-55.

98. See text accompanying notes 111-20 infra (discussion of state income taxes), 186-92 infra (discussion of sales taxes).

99. E.g., Braniff Airways, Inc. v. Nebraska State Bd. of Equalization, 347 U.S. 590 (1954).

100. Indian-related exemptions are derived from the tax-exempt status of protected Indian land, whose purpose is to provide its Indian owner maximum value. See note 19 supra. 
cy requires recognition that it may be imfringed even by a nondiscriminatory tax. ${ }^{101}$

\section{Tribal Sovereignty}

Although property located within an Indian tribe's jurisdiction also should enjoy an immunity from state and local taxation by virtue of the tribal-sovereignty doctrine, courts have been reluctant to use the tribal-sovereignty doctrine as a basis for exempting non-Indian property and activity, possibly because of the concern over further decreasing the states' tax basis. ${ }^{102}$ Despite this reluctance, however, tribal sovereignty should compel the exemption from state taxation of all property and activity on a reservation unless Congress has granted the taxing entity authority to interfere with the tribe's self-government. ${ }^{103}$ The state tax would violate the tribe's sovereign power to tax property located within its jurisdiction whether the land is used by tribal members or is leased to non-Indians. In the first case the tax level is significant be-

101. Such recognition would further the federal policy that Indians attain a standard of living commensurate with that of the population in general. But see Oklahoma Tax Comm'n v. Texas Co., 336 U.S. 342 (1948), in which the Supreme Court upleeld nondiscriminatory state gross production and excise taxes on petroleum produced by a non-Indian lessee from restricted Indian lands. The Court denied the protection of the instrumentality doctrine, overruling Burnet v. Coronado Oil \& Gas Co., 285 U.S. 393 (1932) and Gillespie v. Oklahoma, 257 U.S. 501 (1922), stating:

That inmunity from non-discriminatory taxation sought by a private person for his property or gains because he is engaged in operations under a government contract or lease cannot be supported by merely theoretical conceptions of interference with the functions of government. Regard unust be had to substance and direct effects.

336 U.S. at 362, quoting Helvering v. Mountain Producers Corp., 303 U.S. 376, 386 (1938). No damaging direct effects were found because the reasoning was applicable only to cases involving federal goals of a noneconomic nature. See text accompanying notes 64-72 supra.

The taxes were not attacked as interfering with the Indians' tribal sovereignty, because the lands belonged to individuals rather than to a tribe and were not part of a reservation.

102. See Note, supra note 31 , at 137 . Courts may be more willing to exempt Indian-related property in order to protect federal policy than to recognize a tribe's sovereignty, because of their greater familiarity with the instrumentality immunities of non-Indian cases. See text accompanying notes 60-67 supra. Accordingly, a court might exempt property or activity in order to protect federal Indian policy even though it found that a congressional expansion of state authority over a reservation foreclosed the claim of a tribal-sovereignty immunity. The federal policy analysis [see text accompanying notes 86-101 supra] is also important because it exempts property and activity located on protected Indian land not within a reservation. Such land is not immunized by the tribal-sovereignty doctrine.

103. See text accompanying note 23 supra and cases cited note 20 supra. In McCulloch v. Maryland, 17 U.S. (4 Wheat.) 316, $428-29$ (1819), Justice Marshall called the power to tax an attribute of sovereignty, and a tribal government's legal authority to tax within its jurisdiction is established. Barta v. Oglala Sioux Tribe, 259 F.2d 553, 556 (8th Cir. 1958), cert. denied, 358 U.S. 932 (1959). 
cause the poverty of many tribes makes any tax burden prohibitive, ${ }^{104}$ and in the second the tax burden is important because potential rental value is decreased by any increase in cost associated with the land. ${ }^{105}$ Unless the tribe elects to decrease its own tax, a state or county tax would disrupt the tribe's determination of a desirable tax level. ${ }^{108}$ Moreover, the tribal-sovereignty doctrine also makes state or county enforcement of its tax difficult because the common means of attaching the assessed property in case of nonpayment would be of no avail unless the taxing entity had congressional consent to enter the land in an official capacity.

\section{B. Taxation of Income Derived From Exempt Land}

Whether or not Indian-related income is subject to taxation should be determined according to the effect the tax would have on the function of the special status accorded federally protected land. ${ }^{107}$ A state incoine tax should be void if it interferes with this purpose, ${ }^{108}$ or if it violates a tribe's sovereignty. ${ }^{109}$ Income also should not be subject to federal taxation if the effect on the value of protected Indian land would be detrimental. Unlike the exemption from state income taxation, this federal exemption should exist because Congress did not intend to tax such income rather than because Congress lacks the power to tax it. ${ }^{110}$

104. See The Education of American Indians, supra note 3, at 36; A National Tragedy, supra note 1, at 9; Berger, supra note 3, at 675; Wolf, supra note 3, at 597.

105. A plot of land has an optimum value to a lessee under a given set of circumstances. If the Indians had been successful in maximizing the land's value for themselves, they would collect this amount of money from the lessee. Part of this payment could have been collected in the form of a tribal tax. If a state or local government imposes its own tax on the land it is subtracting from the amount of money the lessee is willing to pay for the land. If the lessee is to continue leasing the land (at least after the lease expires), either the rent inust be reduced or the tribe will have to decrease its tax, unless for an independent reason the land has increased in value.

Indian land is especially vulnerable to state or local taxes since most parties would prefer to avoid the difficulties of dealing with the distant and bureaucratic offices of the federal government that are unavoidable in leasing restricted or trust Indian land. One of the primary lures is the land's immunity to state and local tax. See Record at 75, 78, Agua Caliente Band of Mission Indians v. County of Riverside, 306 F. Supp. 279 (C.D. Cal. 1969). Of course the tax-free status is attractive only if the rent and the tribal tax do not nnake up for the absence of a state or local tax.

106. The argument that property within a city may be subject to state taxation is irrelevant because a tribe is, subject to congressional mandate, sovereign of the statc, whereas a city is not. See Reynolds v. Sims, 377 U.S. 533, 575 (1964), which states that cities and counties are generally subject to the state's authority. A more appropriate analogy is the inability of one state to tax property located in another, absent satisfaction of the due process clause.

107. See Big Eagle v. United States, 300 F.2d 765, 771-72 (Ct. Cl. 1962). Sec note 48 supra.

108. See text accompanying notes 111-20 infra.

109. See text accompanying notes 121-23 infra.

110. See text accompanying notes 124-25 infra. 


\section{State and Local Income Taxes}

Income which is earned on or from exempt land by its Indian owner should be exempt from state taxation ${ }^{111}$ because it would be an even more obvious interference with the federal policy of providing Indians economic assistance than would be taxing personalty which is used to earn the incoine. ${ }^{112}$ Income earned by lessees of protected Indian land should also be exempt from state and local taxation, and it was exempt prior to the demise of the imstrumentality theory. ${ }^{113}$ The lessees were characterized as governmental instrumentalities because they provided revenue for Indians by leasing Indian land. Accordingly, their income could not be taxed by the states. Helvering $v$. Mountain Producers Corp., ${ }^{114}$ a non-Indian case which relied on other non-Indian cases, ${ }^{115}$ expressly overruled that reasoning. ${ }^{116}$ The tax's reduction of the lessee's income from the land was held to be too remote a burden on the protected federal goal, ${ }^{117}$ even though land's rental value was, and is, determincd largely according to its earning potential. Mountain Producers would have been sound had it been limited to the issue before the Court, since the analysis given is appropriate to non-Indian cases. ${ }^{118}$

111. See Squire v. Capoeman, 351 U.S. 1 (1956) [see text accompanying note 41 supra]; Shepard v. United States, 162 F. Supp. 313 (E.D. Wis. 1958) [see text accompanying note 45 supra]. See also United States v. Daney, 370 F.2d 791, 793-94 (10th Cir. 1966), which exempted from state income taxation a lease bonus received by a noncompetent Indian upon the execution of a lease of his allotted land:

[A] lease bonus .... is not the restricted land itself, but a tax on such a bonus is in substance a tax on the land [citation omitted]. [Since] the laud was tax exempt, the bonus was also tax exempt ....

112. See text accompanying notes $90-93$ supra.

113. Gillespie v. Oklahoma, 257 U.S. 501 (1922) and Burnet v. Coronado Oil \& Gas Co., 285 U.S. 393 (1932) prolibited taxation of instrumentalities but were overruled by Helvering v. Mountain Producers Corp., 303 U.S. 376, 387 (1938). For other examples of cases that greatly - restricted the instrumentality exemptions, see United States v. Detroit, 355 U.S. 466 (1958); Oklahoma Tax. Comm'n v. Texas Co., 336 U.S. 342 (1949).

114. 303 U.S. $376,384-87$ (1938). The Court upheld a federal income tax on a state instrumentality because it found the burden on the state too remote to serve as a basis for voiding a federal tax. The Court disregarded the unique economic nature of federal policy concerning exempt Indian lands when it stated that federal instrumentality likewise did not protect Indian-related income from state taxation. For a discussion of the unique nature of the exemption that is provided federally protected Indian land, see text accompanying notes 86-98 supra.

115. 303 U.S. at 385-87, citing Helvering v. Bankline Oil Co., 303 U.S. 362 (1938); Helvering v. Therrell, 303 U.S. 218 (1938); Buruet v. Jergins Trust, 288 U.S. 508 (1933); Willcuts v. Bunn, 282 U.S. 227 (1931) (non-Indian cases in which the success of the governmentally protected policy was not dependent on strictly financial considerations). See notes 64-72 supra.

116. 303 U.S. at 387.

117. Id. at $386-87$.

118. See notes $86-88$ supra and accompanying text. 
Instead, however, the court categorized Indian cases with others, ${ }^{110}$ overlooking that in Indian land cases the income tax places a direct burden on federal policy because the purpose of Indian tax exemption is uniquely economic. ${ }^{120}$

Incoine earned on tribal land should also be exempt from state taxation by virtue of the tribal-sovereignty theory. The primary issue is whether the state has the required authority to interfere with the tribe's self-government. Although one lower state court has ruled that the state has such jurisdiction unless specifically precluded by Congress, the better rule is the converse: Unless Congress has granted to the state the requisite jurisdiction over the tribe and its land, the state may not interfere with the tribe's self-rule. ${ }^{121}$ If the state is not entitled to preeinpt the tribe's self-government, ${ }^{122}$ its attempted taxation of income earned on tribal land should be struck down, for such a tax would vitiate the tribe's sovereignty. Although this is equally true whether the incoine was earned by a tribal member or an outsider, because the tribe would be deprived of the option of determining what tax burden should be borne within its sovereign jurisdiction, only the income of a member has of yet been exempted by virtue of the tribal-sovereignty doctrine. ${ }^{123}$

\section{Federal Income Taxation}

The federal tax status of Indian-related income is determined ac-

119. 303 U.S. at $385-86$.

120. See text accompanying notes 86-98 supra.

121. In McClanahan v. State Tax Comm'n, No. 4370 (Ariz. Sup. Ct., Apache County, Oct. 16, 1969), reprinted in 2 AM. INDIAN NEwSLETTER 281 (1969), an Arizona superior court ruled that the state could tax income earned on a Navajo reservation by a Navajo. The court relied on what it said was a rule derived from Organized Village v. Egan, 369 U.S. 60 (1962). The court quoted a sentence from Egan that stated: "[I]n the absence of a limiting treaty obligation or congressional enactment, each state had a right to exercise jurisdiction over Indian reservations within its boundaries." Id. at 75, quoting New York ex rel. Ray v. Martin, 326 U.S. 496, 499 (1946). It is doubtful, however, that Egan intended this to be a rule, because in the next paragraph the Court summarized the case law, stating:

These decisions indicate that even on reservations state laws may be ap-

plied to Indians unless such application would interfere with reservation selfgovernment or impair a right granted or reserved by federal law.

369 U.S. at 75 (emphasis added).

In the light of previous decisions it seems clear that the or in the quote indicates two independent grounds for prohibiting state action. See Arizona ex rel. Merrill v. Turtle, 413 F.2d 683 (9th Cir. 1969), which relied on the familiar rule of Willinms v. Lee, 358 U.S. 217 (1959), when it stated that the development of "this principle down to its contemporary formulization in Williams prohibits the State of Arizona, in the absence of specific Congressional authorization, from extending its laws or process to the Navajo Reservation if to do so would interfere with tribal self-government or impair a right granted by federal law." 413 F.2d at 685 . See also sources cited note 20 supra.

122. States have been given greater jurisdiction over some tribes than others. 18 U.S.C. \$ 1162 (1964); 28 U.S.C. \$ 1360 (1964).

123. In Commissioner of Taxation v. Brun, 286 Minn. 43, 174 N.W.2d 120 
cording to whether Congress intended to include such income within the broad provisions of the Internal Revenue Code. ${ }^{124}$ Congressional intent is controlling because neither the principle that taxes that frustrate federal policy are invalid nor the tribal-sovereignty principle deny the United States the power to tax Indian-related income. ${ }^{125}$ Two possibly conflicting policies must be reconciled in order to determine whether Congress intended to subject Indian-related income to federal taxation. ${ }^{128}$ The first is that exceptions to the Internal Revenue Code must be exphicit, ${ }^{127}$ and the second is the general federal policy that tax-exempt Indian lands should afford maximum economic benefit to their Indian owners. ${ }^{128}$ Helping to effectuate the second principle is the established rule of statutory construction that requires ambiguous language to be construed in the Indians' favor. ${ }^{129}$

The issue seemed to have been settled in 1935 by Superintendent of Five Civilized Tribes v. Commissioner, ${ }^{130}$ in which the Supreme Court ruled that the federal income tax law, applying as it does to the income of "every individual" and to income derived "from any source whatever," includes Indians and their income unless exempted by agreement or statute. Although the decision was only concerned with reinvestment income, the language indicated that the same principle might apply to income earned directly from exempt land. ${ }^{131}$ However, subse-

(1970), the court struck down a state tax imposed on income earned by enrolled members of Red Lake Band of Chippewa Indians while working on their reservation, stating, "It cannot be argued that siphoning off part of the earnings from employees of a sawmill operated for the benefit and welfare of enrolled members of the tribe does not interfere with the tribal right of self-government." Id. at 53,174 N.W.2d at 126 .

124. INT. REv. CODE of 1954, $\$ 61$. For cases construing income statutes in Indian-related cases, see Superintendent of Five Civilized Tribes v. Commissioner, 295 U.S. 418 (1935) (income from investment of funds earned from use of restricted land subject to federal income tax); Choteau v. Burnet, 283 U.S. 691 (1931) (royalty income from oil and gas lease subject to federal income tax); Shepard v. United States, 162 F. Supp. 313 (E.D. Wis. 1958) (basis of property for federal income tax purposes is the fair market value on the date of termination of the exemption).

125. Congress is not prohibited from imposing a tax that might damage another of its policies, and Congress has the right to govern Indians. Thomas v. Gay, 169 U.S. 264, 274 (1898).

126. Cf. Big Eagle v. United States, 300 F.2d 765, 769 (Ct. Cl. 1962).

127. Superintendent of Five Civilized Tribes v. Commissioner, 295 U.S. 418, 420 (1935); Big Eagle v. United States, 300 F.2d 765, 769 (Ct. Cl. 1962).

128. See note 19 supra.

129. Squire v. Capoeman, 351 U.S. 1, 7 (1956), citing Carpenter v. Shaw, 280 U.S. 363, 367 (1930); Worcester v. Georgia, 31 U.S. (6 Pet.) 515, 518 (1832).

130. 295 U.S. 418 (1935).

131. Id. at 419-21. The earher cases of United States v. Homeratha, 40 F.2d 305 (W.D. Okla. 1930), appeal dismissed, 49 F.2d 1086 (10th Cir. 1931), and Pitman v. Commissioner, 64 F.2d 740 (10th Cir. 1933), had extended the exemption accorded tribal and protected Indian lands to income derived directly therefrom.

In Choteau v. Burnet, 283 U.S. 691 (1931), an Indian who held a certificate of 
quent cases have chosen not to follow the Superintendent dictum when the reasons for an Indian tax exemption have been compelling. Squire v. Capoeman ${ }^{132}$ and Shepard v. United States ${ }^{133}$ both found implied exceptions for the treatment of Indian income for capital gains purposes. In Squire the court explained the reason for finding an implied exemption:

We agree with the Government that Indians are citizens and that in ordinary affairs of life, not governed by treaties or remedial legislation, they are subject to the payment of income taxes as are other citizens. We also agree that, to be valid, exemptions to tax laws should be clearly expressed. But we cannot agree that taxabilty of respondents in these circumstances is unaffected by the treaty, the trust patent or the Allotment Act.

$\cdots$

... To tax respondent under these circumstances would, in the words of the court below, be "at the least, a sorry breach of faith with these Indians." 134

In Nicodemus $v$. United States, ${ }^{135}$ rents derived from tax-free Indian land were held not to be subject to federal income taxation even though they were not specifically excluded by treaty or statute. The court answered the government's contention that Indians are to be included within the scope of the Internal Revenue Code by stating:

[T] his Court, having no exact rule to follow . . . is of the opinion that taxation of income froin trust property as in the present case, would be in violation of the government's agreements with the Indians ... and ... this court should not permit an imjustice such as this.... ${ }^{136}$

Nicodemus ruled that to tax the income at issue would be inconsistent with

the history of the dealings, the treaties and agreements the United States inade with the vanquished Indians prior to the passage of this act [I.R.C.].

... If they may now be taxed, then the obligation which the government has assumed in reference to these Indians may be entirely defeated because it cannot be questioned that if the income tax

competency was taxed on income paid to him as royalties from tribal oil and gas leases. This result was consistent with his unprotected status, although under this Comment's suggestion he might have been afforded the protection despite his competency. See note 53 supra and accompanying text.

132. 351 U.S. 1 (1956). See text accompanying note 41 supra.

133. 162 F. Supp. 313 (E.D. Wis. 1958). See text accompanying note 45 supra.

134. 351 U.S. at 6-10. See also United States v. Hallam, 304 F.2d 620, 622-23 (10th Cir. 1962) (income from the sale of minerals from restricted lands was not subject to federal taxation).

135. 132 F. Supp. 608 (D. Idaho 1955).

136. 132 F. Supp. at 611 . 
is assessed against them, and is not paid, it would become a lien upon their lands and would not be "free of all charge or imcumbrance wliatsoever."137

Squire's reference to "the treaty, trust patent or the Allotment Act," and Nicodemus' reference to the language of the General Allotment Act served to demonstrate that the Indian income was not subject to federal taxation because it was exempted by agreement or statute. The courts in Squire, Shepard, and Nicodemus were willing to find implied exemptions because taxing the income would have been inconsistent with the congressional policy affecting the land from which the imcome was earned. ${ }^{138}$ This approach is consistent with that used in regard to the application of other Indian-related taxes, ${ }^{139}$ and it indicates that income earned on or from protected Indian land by the land's Indian owner, whether legal or beneficial, should be excluded from federal, as well as state, ${ }^{140}$ taxation.

Incoine earned by a noncompetent Indian froin livestock grazing on his tax-exempt land was conceded to be exempt by the Internal Revenue Service in Holt v. Commissioner. ${ }^{141}$ However, the court upheld the Commissioner's contention that income earned by the Indian from the use of the exempt tribal land was taxable, stating that the land's exemption was intended to benefit only the owner-in this case the tribeand not a lessee, even though the lessee was also a protected Indian. The Holt court suggested that it would not have altered its decision if the lessee had been a member of the tribe. ${ }^{142}$ Then it referred to Commissioner v. Walker, ${ }^{143}$ which upheld the imposition of the federal tax on compensation paid froin tribal proceeds from tax-exempt Indian land to a noncompetent Indian for services performed on a reservation. The court had stated in Walker that "[i]f, under the law, the income of an organization is exempt from taxation, it does not follow that the income received by an employee as coinpensation from such organization is also exempt from taxation." ${ }^{.144}$

137. Id. at 610. See also Big Eagle v. United States, 300 F.2d 765, 771 (Ct. Cl. 1962), which stated that the spirit of Squire v. Capoeman, 351 U.S. 1 (1956), requires not extending the lauguage of the federal mcome tax law, broad as it is, to trust-land imcome of a noncompetent Indian, even though there is no "definitely expressed exemption in the tax law. ..."But see Superintendent of Five Civilized Tribes v. Commissioner, 295 U.S. 418, 420-21 (1935).

138. See text accompanying notes 86-98 supra.

139. See text accompanying notes 86-98 supra (personal property), 111-20 supra (income).

140. See text accompanying notes 111-20 supra.

141. 364 F.2d 38 (8th Cir. 1966).

142. Id. at 41 .

143. 326 F.2d 261 (9th Cir. 1964).

144. Id. at 264 . 
Although this rule is generally valid, it is not suited to the peculiarities of Indian cases because the relationship between a tribe and its members bears little resemblence to that between most tax-free organizations and their employees or stockholders. Exemptions of tax-free organizations $\mathbf{1 4 5}^{\mathbf{4 5}}$ are based on the organizations' socially desirable goals, and not on benefit to the organizations' stockholders or employees. Tribes differ in that they exist for the benefit of tlieir members, many of whom are federal wards. Tribal tax exemptions are provided because the meinbers are owed a special responsibility by the federal government. ${ }^{146}$ Income earned from the land by protected imdividual members should be exempt if it would be exempt when earned by the tribe; it is doubtful that the federal government intended the land's protection to benefit the tribe as an entity distinct from its members. ${ }^{147}$

Income earned on protected Indian land by a non-Indian lessee was held subject to federal taxation in Heiner $v$. Colonial Trust Co. ${ }^{148}$ on the ground that income of other governmental imstrumentalities is subject to taxation. ${ }^{140}$ The comparison to non-Indian instrumentalities was unfortunate, although typical, ${ }^{150}$ because the achievement of federal Indian policy is peculiarly vulnerable to increased financial burdens. $^{151}$ Just as state power to tax mcome earned on exempt Indian land by non-Indian lessees should be denied to preserve federal pohcy, the courts should rule that Congress did not intend to hinder national Indian policy by subjecting such income to federal taxation. ${ }^{\mathbf{1 5 2}}$

There are, of course, limits to this doctrine. Proceeds from the investment of immune direct income should be subject to federal taxation when the necessary condition for an Indian exemption is lacking,

145. See INT. Rev. CODE of 1954, $\S 501$ (exempt organizations), 503 (requirements for exemption).

146. See note 17 supra and accompanying text.

147. This exemption should not extend to an Indian who is not a member of the tribe which owns the land, even though he may be of noncompetent status, unless his use of the land is pursuant to a federal program designed to further the economic development of Indians. See Sohol v. Clark, - Wash. 2d -, 479 P.2d 925, 927-28 (1971), in which the Washington supreme court ruled against county taxation of personal property owned by a noncompetent Indian and used in a business on the reservation of another tribe. Otherwise there is no evidence that the land's exemption was meant to benefit him. However, his imcome should enjoy an exemption if he is a lessee of the land, because to tax his income would decrease the land's rental value, which would deprive the tribe of the land's maximum value. See text accompanying notes 152-54 infra.

148. 275 U.S. 232 (1927).

149. Id. at 235.

150. See text accompanying notes 73-85 supra.

151. See text accompanying notes 86-98 supra.

152. However, the Internal Revenue Service feels otherwise: In a letter from the United States Treasury Department to the United States Department of the Interior, July 14, 1970, the Treasury Department outlined a list of proposals to Congress con- 
that is, when the income is not produced on or froin the protected land. This requirement places a rational limitation on Indian-related tax exemptions. ${ }^{153}$ It is especially necessary to have an easily administered limitation in the area of federal income taxation because courts are extremely reluctant to find implied exemptions to the Internal Revenue Code. ${ }^{15 t}$

\section{Death Taxes}

\section{State Inheritance Taxes}

The land tax exemption is afforded as a means of aiding the Indians' economic development, ${ }^{155}$ a federal goal which is important because of the extreme poverty of most Indians. ${ }^{156}$ The same protective policy should also exempt from state inheritance taxes Indian property that is immune from direct taxation when owned by both the decedent and the beneficiary. ${ }^{157}$

Courts have generally held that property which is exempt from direct taxation is also exempt from state inheritance taxes. Thus in Childers v. Beaver ${ }^{158}$ the United States Supreme Court stated that land exempt from real property taxation is under the protection of the federal government ${ }^{1 \bar{v} 9}$ and thus not subject to state inheritance taxation so long as it remains restricted. Similarly, in Kirkwood v. Arenas ${ }^{160}$ the proceeds from the sale of exempt land were excluded from a state inheritance tax in order to preserve the benefits which the protected land was intended to provide. A shight deviation from Beaver was Oklahoma Tax Commission v. United States, ${ }^{161}$ in which the Supreme Court upheld the inheritance tax when it was applied to the transfer of property which was restricted but not exempt from direct taxation. However, consistently with the suggested principle, the Court voided the tax as

cerning the taxation of Indians and Indian tribes. Included were the proposals that individual Indians be subject to federal income taxes on incoine from all sources, including income from trust allotments, and that incoine earned from tribal business enterprises also be subject to federal taxation even if the income-producing asset is held in trust.

153. See text accompanying notes $90-93$ supra.

154. See sources cited note 127 supra.

155. See text accompanying notes 86-98 supra.

156. See text accompanying notes $3-4$ supra.

157. The requirement that the property be exempt when owned by the decedent prevents the increase of exempt Indian property. In addition, together with the second requirement, it assures that the property remains protected only for the benefit of a person for whom the federal government has undertaken a special responsibility. See text accompanying note 50 supra.

158. 270 U.S. 555 (1926).

159. $1 d$. at 559 .

160. 243 F.2d 863 (9th Cir. 1957).

161. 319 U.S. 598 (1943). 
applied to property exempt from direct taxation, the distimction being that the direct taxation exemption was the necessary evidence of Congress' intent to provide an Indian tax privilege. In West v. Oklahoma Tax Commission ${ }^{162}$ the Supreme Court extended Oklahoma Tax Commission to impose similar treatment on trust property, since trust and restricted property are essentially the same. ${ }^{163}$ Unfortunately, the West Court ignored a crucial difference between the restricted property that was involved in Oklahoma Tax Commission and the trust property then before it: The trust property before it was exempt from direct taxation while the restricted property in Oklahoma Tax Commission that was subjected to the inheritance tax was not. This distinction is important because the purpose of the property tax exemption is seriously eroded if exempt property is depleted by an inheritance tax, whereas no unusual damage to federal policy occurs from imposing inheritance tax on property already subject to ordinary property taxes. The applicability of an inheritance tax should be determined according to whether or not the property is subject to direct taxation, regardless of the property's designation as trust, restricted, or unrestricted.

\section{Federal Estate Taxes}

Indian-related exemptions from federal taxation differ from state tax exemptions because Congress, unlike the states, is clearly authorized to tax Indians and their property. ${ }^{164}$ However, since Congress is unlikely to impose a federal tax when a similar state tax would be so damaging to national policy that it could be struck down, the considerations that are used to determine the permissible scope of state inheritance taxes are also relevant in seeking Congress' intended application of federal estate taxes to Indian-related property.

This approach was used in Landman $v$. United States, ${ }^{165}$ when in a federal context the Court of Claims relied upon the state tax reasoning of Oklahoma Tax Commission v. United States. ${ }^{166}$ Recognizing that preservation of the protection afforded by the direct tax exemption requires that the property also be exempted from the often substantial es-

162. 334 U.S. 717 (1948).

163. Id. at 726. West distinguished the immunity of Indian trust property from property taxation by stating that the inheritance tax is imposed on the shifting of economic benefits rather than on the property itself. Id. at 727 . What this distinction ignores is that, although the depletion of estates may generally be desirable, the federal government has indicated that exempt Indian property is entitled to special protection. See text accompanying notes 86-98 supra.

164. Landman v. United States, 71 F. Supp. 640, 647, (Ct. Cl. 1947). See also notes 124-25 supra.

165. 71 F. Supp. 640 (Ct. Cl. 1947).

166. 319 U.S. 598 (1943), discussed in text accompanying note 161 supra. 
tate $\operatorname{tax}_{,}{ }^{167}$ the court held that the property was not includable within the taxable estate. ${ }^{108}$

This position, however, has not been uniformly adopted. One circuit that declined to infer a federal estate tax exemption from a direct taxation immunity did so because it fell victim to the practice of using instrumentality-doctrine reasoning without taking into account the uniqueness of Indian tax cases. Thus Landman v. Commissioner ${ }^{169}$ denied an instrumentality exemption because it did not recognize that the federal obligation to Indians is fulfilled by affording Indians maximum economic benefits. ${ }^{170}$ The court distinguished the property tax from the estate tax, stating that the former is imposed on the property, which is exenupt, while the latter is on the shifting of property. ${ }^{171}$ This reasoning ignores the reason for the property's privileged status. Since the protection of the direct tax immunity is also defeated by imposition of the estate tax on the shifting of the exempt property, the court should have ruled, as did the subsequent case of Landman $v$. United States, that the property's exemption is proof of Congress' intent to exclude such property froin the reach of the federal estate tax.

\section{Possessory Interests}

\section{Impairing Indian Land's Governmental Function}

The use of possessory interest taxes has been advocated as a means of circumventing the exemption enjoyed by protected Indian land. ${ }^{172}$ The reasoning is that the tax is assessed against only the lessee's interest in the land, which is supposedly taxable because it is the property of an instrumentality. ${ }^{173}$ The supporters of the tax suggest that the taxing entity's inability to attach the underlying land as security in case of nompayment is proof that the tax is not a direct interference with federal policy. ${ }^{174}$

167. See INTERNaL REVENUE CODE OF 1954, § 2001.

168. 71 F. Supp. at 648. See also Nash v. Wiseman, 227 F. Supp. 552 (W.D. Okla. 1963), which ruled that a trust allotment owned by a noncompetent heir of the original allottee, and accumulated funds arising from the sale of minerals from the allotment, were not subject to federal estate taxation.

169. 123 F.2d 787 (10th Cir. 1941). This case is not related to Landman v. United States, 71 F. Supp. 640 (Ct. Cl. 1947), discussed in text accompanying notes 164-68 supra.

170. See text accompanying notes 86-93 supra.

171. 123 F.2d at 790 .

172. Note, supra note 31 , at $146-47,149$.

173. This argument, of course, treats the lessee as the instrumentality, rather than the land, and relies on the non-Indian instrumentality formula that should not apply to exempt Indian land. For a critical analysis of this approach see text accompanying notes 86-98 supra.

174. The possessory interest tax is not assessed against the underlying property, 
In the leading possessory interest tax case, United States $v$. Detroit $^{175}$ the Supreme Court upheld taxation of the lessee's interest in tax-exempt land owned by the United States, even though the land's rental value was decreased by the tax. Fundainental to this decision is the assumption that the achievement of federal policy is not dependent upon financial considerations, ${ }^{176}$ an assumption that was correct on the Detroit facts if the government's primary interest in leasing the land was to have the lessee's industrial activity performed rather than to accomplish federal policy by maximizing the land's profitability or to confer financial benefits upon the lessee by virtue of a tax exemption. ${ }^{177}$

However, Agua Caliente Band of Mission Indians v. County of Riverside ${ }^{178}$ followed Detroit so literally that it upheld a county tax on the possessory interests of lessees of protected reservation land owned by an individual despite the recognition that the cost ultimately would be borne by the Indian owners. ${ }^{179}$ This approach wholly misconstrues the policy to enable the land to serve as the Indians' base for economic development, a growth that is stunted by inpairment of the land's value. ${ }^{180}$ Federal policy is usually dependent upon financial considerations in Indian-related cases, ${ }^{181}$ therefore, taxes on possessory interests in protected Indian property should be struck down because they frustrate federal policy by decreasing the property's value.

\section{Tribal Sovereignty}

Possessory interest taxes also violate the tribal-sovereignty doctrime if the underlying property is within tribal jurisdiction. Since the possessory interest tax interferes with the tribe's ability to determine the tax level within its jurisdiction, it interferes with a tribe's self-government in the same manner as taxes on personal property located on land sub-

which cannot be levied upon even if the tax is not paicl. $C f$. Nicodemus v. United States, 132 F. Supp. 608, 610 (D. Idaho 1955); Makah Indian Tribe v. Clallam County, 73 Wash. 2d 677, 685, 440 P.2d 442, 447 (1968). However, this argument in favor of the tax would be dispositive only if the single purpose of the tax immunities were to assure that the underlying property is not lost through a tax sale. In fact, the exemptions are provided so that the Indians can derive maximum value from their land [see text accompanying note 19 supra]. See United States v. Daney, 370 F.2d 791, 795 (10th Cir. 1966); Big Eagle v. United States, 300 F.2d 765, 770-72 (Ct. Cl. 1962); Makah Indian Tribe v. Clallam County, 73 Wash. 2d 677, 685, 440 P.2d 442, 447 (1968).

175. 355 U.S. 466 (1958).

176. Id. at 472 .

177. See text accompanying note 83 supra.

178. 306 F. Supp. 279 (C.D. Cal. 1969).

179. Id. at 282 .

180. See text accompanying notes 86-98 supra.

181. A different basic assumption can be shown in unusual circumstances such as were found in Detroit. 
ject to tribal authority; that is, by interfering with the tribe's right to determine the tax rate within its jurisdiction. ${ }^{182}$ If the land is leased, the interference of the possessory imterest tax may be greater than that of the personal property tax, because the value of taxable property located on the land may be relatively small in comparison to the value of the leasehold. In such a case, a tax on the property would be but a small portion of the cost of using the land. There is thus potentially greater leverage with the possessory interest tax because it is figured on the value of the leasehold itself, and the tax may be a significant increase in the total cost of the land's use. Therefore, the possessory interest tax can be an even greater interference with the tribe's selfrule. ${ }^{183}$

That courts are able to strike down taxes that would completely destroy a federal instrumentality's activity ${ }^{184}$ does not mean that the states are free to make lesser encroachinents upon a tribe's self-rule without congressional authorization. ${ }^{185}$ Since tribal sovereignty from state interference should protect a tribe's influence over how it exists as well as whether it exists, tribal sovereignty should prohibit all state taxes which interfere with a tribe's right of self-government and not just those which pose an immediate threat to the tribe's existence.

\section{E. Sales Taxes}

\section{Protecting Federal Policy}

Taxation of sales occurring on protected Indian land diminishes the land's value by decreasing its profit potential, much as does the taxation of personal property located on such land. ${ }^{186}$ The reasons for invalidating taxes on personal property located on exempt Indian land similarly require that state and local taxes be struck down if they are imposed on sales occurring on such land. ${ }^{187}$

To help prevent retail businesses from locating on protected Indian land in order to offer tax-free sales to everyone in the surrounding area, the state or local government could impose a tax upon the use of the

182. See text accompanying notes 103-06 supra.

183. In the context of the tribal-sovereignty doctrine, the tax's detrimental effect on the land's value is significant not because of the interference with the land's federal purpose [see text accompanying notes 86-98 supra] but because encroachment on a government's self-rule increases with the tax's adverse influence on activity within that government's jurisdiction. See text accompanying notes 24-26 supra.

184. See note 72 supra and accompanying text.

185. See note 23 supra and accompanying text.

186. See text accompanying notes 93-97 supra.

187. The location of personal property on Indian land should be a necessary and sufficient condition for exemption from a local property tax. See text accompanying notes 94-97 supra. Similar reasoning requires that activity on Indian land also be 
product when it is taken off the protected land. ${ }^{188}$ Requiring the activity's situs to be on Indian land establishes an easily administered test that also furthers the federal policy of encouraging development of Indian land by guaranteeing the exemption only so long as the property sold is kept on such land: If the local government adopts a use tax on property sold on but subsequently removed from Indian land, ${ }^{180}$ the effect of this situs test is to limit the benefit of the sales tax exemption to sales of property that remains on the protected land.

Of course the use tax will fail in this role if it cannot be collected inexpensively by the state. States which have employed the use tax to circumvent the commerce clause's ban on the taxation of imterstate sales have often attempted to require the out-of-state seller to collect the tax on property sold to users in the taxing state. ${ }^{100}$ Such attempts generally have becn upheld when the seller has some contact with the taxing state, such as a branch office ${ }^{101}$ or a traveling salesman, ${ }^{102}$ especially if the goods are sent by the seller to a buyer located in the taxmg state. This latter may be a necessary requirement in order that the seller may know the property is going into the taxing state.

States should be able to require sellers located on protected Indian land to collect a use tax on goods that will be used within the taxing state if the state constitutionally could require a seller in another state to collect the tax under the same circumstances. This should be true despite the tribal-sovereignty doctrine, because Indian tribes surely are no more sovereign of the taxing state than were the states of the sellers involved in the commerce clause cases. If the constitutional requirements are not met the state would have to resort to other collection means, such as collecting the tax upon the registration of a notor vehicle or the

exempt. See text accompanying note 98 supra. But see Note, supra note 31, at 148, in which the author argues that federal preemption [see text accompanying notes 194-95 infra] is the only bar to the state sales tax.

188. For possible means of frustrating the attempt to use Indian land's protected status as a haven from personal property taxes, see note 93 supra.

189. A local government probably could himit the use tax to property not previously subject to its sales tax (because it was sold on protected Indian land), but a credit probably would have to be given for any sales tax paid to the tribal governinent. See Southern Pac. Co. v. Gallagher, 306 U.S. 167 (1939) and Henneford v. Silas Mason Co., 300 U.S. 577 (1937), which deal with the use tax as a means of circunnventing the prohibition on state taxation of interstate commerce. See generally Shoup \& Haimoff, The Sales Tax, 34 Colum. L. Rev. 809 (1934); Traynor, The California Use Tax, 24 Calif. L. Rev. 175 (1936).

190. See, e.g., Nelson v. Sears, Roebuck \& Co., 312 U.S. 359 (1941); Notc, Sales and Use Taxes: Collection from Absentee Vendors, 57 HARv. L. REv. 1086, 1093-96 (1944).

191. See, e.g., Nelson v. Sears, Roebuck \& Co., 312 U.S. 359 (1941).

192. See, e.g., Miller Bros. Co. v. Maryland, 347 U.S. 340 (1954). 
use of a self-assessinent system similar to that of the federal income $\operatorname{tax}$.

\section{Tribal Sovereignty and Federal Preemption}

The tribal-sovereignty doctrine should also bar a state or local sales tax if the sale takes place on exeinpt land within the authority of a sovereign tribe. The determinative issue should be the extent of the particular tribe's sovereignty, which can be limited only by Congress, ${ }^{193}$ since the tax would interfere with the tribe's self-government by denying the tribe the option of deciding the tax level which should be borne by transactions occurring within its jurisdiction, whether or not the customer is a tribal member.

It inay also be that the federal government has occupied the sales tax field. In Warren Trading Post Co. v. Arizona Tax Commission ${ }^{194}$ the Supreme Court voided a state sales tax which was levied against sales of a company doing a retail trading business with Indians on a reservation because Congress has preempted the right to regulate or burden such activity. The Court referred to the comprehensive federal legislation dealing with trading on the reservation and the absence of provision for state or local non-Indian participation. ${ }^{195}$ Although the preemption approach made the tribal-sovereignty doctrine unnecessary, the Court did recognize that the federal government often intends to make tribes independent of state and local jurisdiction. ${ }^{196}$ Thus, preemption considerations combine with the sovereignty doctrine in militating against a sales tax on Indian territory.

\section{CONCLUSION}

Although Congress has generally afforded Indians special tax treatunent by dealing expressly with real property, the federal purpose of providing financial assistance to Indians requires that the scope and validity of all Indian-related taxes be determined according to the tax's effect on the value of the exempt land. The basic primciple that taxes that frustrate federal policy must be voided will yield correct results in both Indian and non-Indian cases, but only if the appropriate federal policy is identified on a case-by-case basis. Since federal Indian policy differs from the policies underlymg most other federal functions because of its basic commitment to economic improvement, inany Indian-related taxes should be struck down because they create a financial

193. See note 103 supra and accompanying text.

194. 380 U.S. 685 (1965).

195. Id. at 688-90.

196. Id. at 690 . 
[Vol. 59:1261

burden, even though similar effects on other federal programs would be permitted. Courts must therefore resist the temptation to judge Indian-related taxes according to formulas developed in non-Indian cases.

Richard L. Perez 